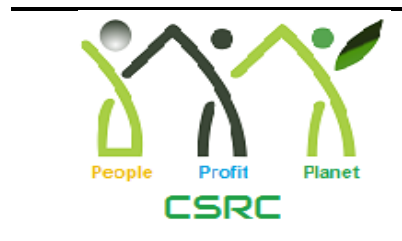

Volume and Issues Obtainable at Center for Sustainability Research and Consultancy

Journal of Business and Social Review in Emerging Economies

ISSN: 2519-089X (E): 2519-0326

Volume 4: Issue 1June 2018

Journal homepage: www.publishing.globalcsrc.org/jbsee

\title{
The Effects of Total Quality Management as Teaching Innovation and Job Satisfaction on Academic Performance of Students in Pakistan
}

\author{
${ }^{1}$ Waqas Mahmood, ${ }^{2}$ Siti Noor Ismail \\ ${ }^{1}$ Ph.D Scholar, School of Education and Modern Languages, Universiti Utara Malaysia, \\ waqasmahmood44@gmail.com \\ ${ }^{2}$ Lecturer, School of Education and Modern Languages, Universiti Utara Malaysia, siti.noor@uum.edu.my
}

\begin{tabular}{l}
\hline ARTICLE DETAILS \\
\hline History \\
Revised format: May 2018 \\
Available Online: June 2018
\end{tabular}

\section{Keywords}

Total Quality Management,

Teaching Innovation, Job

Satisfaction, School

Achievement

\section{JEL Classification:}

L15, L19, Q55

\begin{abstract}
This conceptual paper focuses on the effects of total quality management on students' academic achievement of secondary school students in Pakistan with teaching innovation and job satisfactions. Generally, teaching innovation as part of total quality management is considered as the most important factor in education system. Even though teaching method is an issue in students' academic performance, teachers' capacity building has remained a contested issue in Pakistan. There is a remarkable gap in the provision of quality teachers and students performance in Pakistan; this is as a result of unqualified teachers in the schools. Therefore, this paper discusses the effect of learner-centred method of teaching as innovation on students' performance and the influence of teacher capacity development as a factor in academic attainment of the school researches have shown that improvement in teaching methods and little spending on teachers' development training are associated to increase in school achievements.
\end{abstract}

(C) 2018 The authors, under a Creative Commons Attribution-

NonCommercial 4.0

Corresponding author's email address: waqasmahmood44@ gmail.com

Recommended citation: Waqas Mahmood, W., Ismail, S.N. (2018). The Effects of Total Quality Management as Teaching Innovation and Job Satisfaction on Academic Performance of Students in Pakistan. Journal of Business and Social Review in Emerging Economies, 4(1) 107-116

DOI: $10.26710 /$ jbsee.v4i1.373

\section{Introduction}

Resent researchers have shown that learner-centred method of teaching has great influence in improving student's achievement and motivation (Caprara, Barharanelli, Steca \&Malone, 2006). As well as teacher development through training and motivation can contribute to the growth and development of the school achievement as teachers gain experience ((Tschannen \& Woolfolk, 2007; Wolters, 2007)). In spite of the benefits associated with teacher capacity development in school and students' achievement, little is been done in Pakistan to help teachers gain more experience through in service training (Lee, 2011). The development of teacher by training and incentives from researcher has shown motivation, skills, knowledge and effectiveness (Tahidu, Bawa, and Abubakari, 2014). The use of TQM in schools has is a welcome development in school system where the school is forced to follow the priciples of TQM. Therefore, this article will go a long way to contribute to the development of education in Pakistan and the world at large.

\section{Literature Review}

According to Oakland (1989), and Goetsch and Davis (1994) total quality management is trying to attain 
fast recognition as a model in many organizations but cannot be realized immediately because it takes time to bring together the right principles of qualify and strategies into organizations of which school is one. Human resources as well as time and activities are TQM requirements that are highly important for school success. Therefore, it awareness of TQM is central to teaching and achievement. To Tahidu, Bawa, and Abubakari (2014) TQM in education is not just promoting quality in the classroom, but it is also taking care of the human resources as well as spreading information about it around. They are also of the opinion that TQM popularity should be extended to how school authorities and managers react and address quality management. Researches have shown that TQM awareness is sometimes limited despite the fact that it is necessary.

The question now is, how can TQM be integrated into the school system to improve students' and school achievements in places where it is not popular and practiced? Therefore, this paper intends to explore the effects of TQM on students' academic achievement in Pakistan where the awareness is not well pronounced. Therefore, TQM is defined by Tahidu, Bawa, and Abubakari (2014), as 'total organizational approach for meeting customer needs and expectations that involves all managers and employees in using quantitative methods to improve continuously the organisation's processes, products and services." TQM can be divided into two: hard and soft side of TQM, for this paper emphasis will be placed on the last.

TQM is identified soft with some principles that are most common in quality management as can be seen in the framework of this study. The first principle is that TQM in education engages everybody in the school system. This principle supports the involvement of stakeholders in running the school lead to high circulation of knowledge and information among the teachers and students, thereby increasing performance of students and school achievement (Powell, 1995). Morgan and Murgatroyd (1997) agreed that, the principles of TQM imply that, every employee of any system or organization should be involved in the school quality improvement processes likewise other organizations. Oakland (1989) also added that TQM is particularly a way of involving and organizing the school system including classroom activities, all the departments, and every staff and students of the school or educational sector. The second principle has to do with continuous improvement of the school facilities. According to Ho and Fung (1994), Goetsch and Davis (1994), and Dale (1996) agreed that the right manner to improving educational or organizational outcome in TQM theory is regular development of workers through training for better performance of staff and that there is no limit or end to it since education is dynamic. So emphasis should be on enhancement opportunities for teachers in order to improve students' and school achievement. The focus of school authorities should be planning, prevention, and anticipation (Dale, 1996).

Furthermore, Juran (1988) observed that improvement of TQM requires needs quality drive to facilitate continuous improvement that never ends by providing necessary support for staff development. The third principle of TQM according to Tahidu, Bawa, and Abubakari (2014) has to do with relating to the concept of teamwork. Which is essential situation for progressing empowerment and outputs of staff to be strong and effective group work rather than individuals, it has to include employees from all levels in the departments of any organization or schools for flexibility and mutual trust among members.

In school organization TQM, there is need to care about quality improvement through organization interconnected work groups that look at the needs of departmental management problems and empowering teachers to improve in ability, to be more confident, and committed to their jobs by improving the process of teaching and learning to satisfy customers (parents) requirements. Customer satisfaction in TQM of school is to provide the adequate facilities to enhance the performance of students who are the outcome or output of the school.

According to Juran (1993) and Tahidu, Bawa, and Abubakari (2014) suggested that customer satisfaction in school organization can be viewed in two different ways, such as external and internal. The external perspectives of the school are: the students, the government agences, and the public that determine the quality of the service delivered at schools. While the internal perspectives are the teachers in the different 
departments of the school who are responsible for the quality teaching that is associated with the delivering of services in schools. TQM emphasises the importance of both external and internal needs of customers and importance associated with satisfying those needs. Therefore, to meet customers'/students satisfaction, every member of the school organization must believe in continuous empowerment as necessity. Schools/organizations should keep records of students' performance as data, parents'/customers' complaints, and benchmark in order to enhance the parents'/customers' demand. In other words, to realize the principles of TQM the top school management must be commitment by giving support to teachers and enhance teaching/learning facilities.

From these writings and the case studies, it is possible to identify a number of critical factors in the TQM implementation process that are common to successful TQM programmes. These are outlined below.

- Top Management commitment: Clear leadership and vision is required and senior management must demonstrate a commitment to TQM and be actively involved in the TQM process. Management should set an example by managing quality as a key strategic issue and supporting continuous improvement.

- Training and education: education and training should cover all employees as part of an on-going process, with the scope and depth tailored to suit each group's needs.

- The involvement of Staffs: Involvement in the TQM process is a key determinant of a successful programme. Until everyone is involved in the process of quality improvement, there is a major cost of lost opportunity being carried by the organization.

- Continuous improvement: the specific TQM objectives and requirements of the organization must be determined. The TQM activity must be incorporated into the organizations' business plans and the means for continuous improvement established.

- Quality technologies: quality technologies, such as SPC, quality costing, benchmarking, DPA etc., provide the techniques to identify opportunities and solve problems. They enable continuous improvements and reductions in variation to be achieved.

\section{Reasons for Total Quality Management in Schools}

TQM principles for enhancement of learning cannot be underestimated in it roles in education. It should be based on outputs rather than on inputs so the products of schools are determined by its structural characteristics. The determiner for schools' quality has to do with achievement / performance at average examination scores, faculty qualification, library facilities, students/department ratios, acceptance rates, and endowments (Sims and Sims, 1995). On the other hand, Divine, Miller and Wilson (2006) described the proponents of TQM in schools needs should focus on the outcomes of teaching process rather than on the quality of intakes. The needs of the teachers which determined the outcome of the school should be paramount in the minds of the school management and government. According to Allen (2007) school assessment is related to the activities designed to monitor and improve student learning through well stated goals in school programmes for learners, affirming the integration of the goals into the curriculum to measure the extent of the achievement of the goals and whether the learners have meet the objectives and then have rethink on their syllabus and activities in order to improve learning process as well as future achievements of students. To improve performance in school environment the necessary materials for teaching and learning must be adequate and available. Teachers should be given the opportunity for further training, providing relevant books and other materials for efficient teaching and learning. Allen added that qualified teachers and a well-equipped library with adequate funding are prerequisites for better achievements in schools.

\section{TQM and School Performance}

In the new dispensation, schools have taken the issues of TQM seriously to add values to output of the schools which have the establishment of quality assurance units in schools. Murad and Rajesh (2010) and Tahidu, Bawa, and Abubakari (2014) among other TQM researchers are of the opinion that the quality of schools take into consideration the external environment where learning is taking place and the internal 
environment where the activities of teaching and learning are taking place.

Another role of TQM on school performance has to do with the process for assessing students and the overall assessment of teachers and the school achievement generally. It should be noted that students' performance is used to judge the performance of the teacher and school. According to Murad and Rajesh (2010) and Alabere, Hassan, and Suleiman (2015) the more successful students are the higher the success of the school or institution. The school heads should ensure that the aims and objectives of schools are achieved through assigning qualified teachers to handle professional courses by employing the right hands. This success contributes to the development of knowledge, excellence, and expertise that lead to the growth of nation's educational system and economy which cannot be underestimated and it cannot be achieved without the financial support of the Government. Many factors are responsible for TQM ineffectiveness in achieving its aims in school setting, the constraints for implementing TQM in schools are:

1. Insufficient knowledge of how to incorporate TQM principles in school.

2. Lack of management commitment affects the implementation of TQM in schools.

3. The inappropriate structural organization of school can affect TQM.

4. Shortage of funding is another problem of TQM in school.

5. Lack of commitment of teachers

6. Poor data, ineffective leadership and contradictory policies can also affect TQM.

\section{Why the Need for TQM in Schools}

The role of TQM in developing quality education cannot be overlooked. The school should focus more on the quality of output rather than input. The output of schools/institutions depends primarily on the teachers and the structural characteristics of the school. According to Sims and Sims (1995), the quality of school output based on achievement includes input level of the students, quality of teachers, acceptance rates, teachers' qualifications, infrastructures, books in library and students and department ratios. Also of the same opinion are Divine, Miller, and Wilson (2006) who attested that TQM in school should emphasize more on the outcomes of the school system rather than on the inputs. The researchers concluded that TQM be regarded as the level to which the needs of the teachers are met to achieve the desired outcomes of the school. Allen (2007) also contributed that the school should monitor assessment and enhances learners' learning. Assessing learners' achievement includes understanding the aims and goals in learning programmes for learners, the objectives should integrated to the curriculum, so that the extent to the objectives are realized by students can be measured and then make adjustments to the curriculum where necessary to improve their learning in future performance of the students. Therefore, schools have to find ways to improve the standards of their teachers to be more effective and should be a continuous improvement process.

\section{TQM and School Achievement}

Total quality management in schools has gained ground and considered in assessing school output to add values to outcome of schools. TQM has brought about the creation of quality assurance units in schools in most countries. Total quality management researchers like Murad and Rajesh (2010) believed that TQM in schools takes into consideration external facilities for learning in schools while the internal environment refers to where teaching and learning are carried out including home environment of students. Teachers should undergo continuous training in some key aspects of education: they should be trained to acquire new methods of teaching and learning, training on the new assessment strategies, and training on latest classroom management techniques (Popham, 2010). All these have effects on achievement of schools. Therefore, TQM strategy is not for school achievement only but to have imparted on all aspects of school system such as interpersonal relationship, human and material resources, management, and organization. TQM helps to reform activities of the school through change in attitudes of school management in monitoring and school activities as well as the evaluation of results. TQM as a way of life in school system must focus on creating enabling environment for teaching and learning, 
constant improvement of staff and involvement of all workers. Organizing co-curricular activities in school is another way TQM has influence on school achievement. According to Alabere, Aspalila and Hassan (2015) agree that co-curricular activities if well organized by school heads, principals, and teachers will go a long way to improve and enhance students' achievement and school popularity. Necessary materials should be put in place to motivate learners' participation in the school activities bringing about school achievement socially and academically.

\section{Teaching Innovation}

Decades back there was agitation on how to enhance students' achievement in the country' schools despite increase in the cost of living and education there has been no increase in the achievement of students and schools. It is necessary therefore, to move away from teacher-centred approach to studentcentred approach. Teaching innovation according to Lee (2011) is the outcome of learning when the right methods are used through interaction between the students and the learning environment. Lin (2002) also contributed by seeing teaching innovation as teacher's ability to make teaching lively by involving students actively in learning skills to develop ability to think and being creative. Wu (2002) added that enhancing positive attitude to learning from personal interest is teaching innovation. Therefore, the trend of teaching innovation is when a teacher is able to adopt new teaching methods, develop materials and concepts that motivate and stimulate interest in students to wanting to learn.

Teaching innovation helps teachers to establish activities that can stimulate students to learning and active participation in the classroom. According to Jones (1996) learning style and other factors help students to learn effectively and this influences the school achievement and students' performance grades. For effective teaching innovation, teachers have to practice the following:

1. Teacher must be conversant with course contents and the appropriate method and activities to employ in teaching the learners.

2. Upgrade teaching quality and effectiveness

3. Students' assessment should be diversified by knowing the learners' individual differences and treat them separately.

4. Through teaching innovation, the educational aims and objectives should be achieved by the teacher.

The above mentioned will help the teacher to achieve success by involving learners in the following;

1. Enhancing learners' motivation and interest for learning.

2. Developing students' ability to think, solve problems and be independent.

3. Improving students learning through active participation.

4.

Innovation teaching helps teachers to develop and apply characteristics of positive traits and moral virtue from experience to modify students' characters to positive thinking and outlook on life generally by presenting good moral character. According to Lee (2011) innovation in teaching has to do with, adopting new methods and materials for teaching new ideas through creative and effective approaches that will make learning meaningful and interesting to students. In other words, teaching innovation is applying new materials developed bu the teacher or by someone else for teaching, adopting and vary methods and strategies of imparting knowledge, and effective teaching of concepts. Based on the views of scholars there is similarity between creative teaching and teaching innovation.

This paper regards creative teaching which is teaching innovation and job satisfaction as dimensions to Total Quality Management of school. Therefore, teaching innovation has to do with activities in the classroom with relation to students while job satisfaction has to do with teachers' incentive motivation from their employers.

\section{Innovation in Teaching and Learning Effectiveness and Learning Satisfaction}

Much has been said about teaching innovation above. Learning satisfaction according to Jones (1996) and Hoffman (1996) are of the view that digital teaching can increase learners' motivation to learn and 
achieve. Integrating information technology into teaching process can be said to be the best approach for teachers to improve the methods and skills of teaching. Integrating technology to teaching helps learners in solving issues/problem and innovative teaching that is not an easy task to accomplish due to need for cooperation. In other words, some difficulties may be encountered when carrying out integration of information technology into teaching. Such problems are environmental issues, time, man-made issues, subject issues and integration problems. If these difficulties are solved, there will be positive impact of teaching innovation and learning satisfaction.

Learning satisfaction includes four dimensions: the materials for teaching, teaching activities, the learning environment and interpersonal relationships. Biner (1997) in his study observed that learners learning satisfaction from watching teaching on television using subject teachers, technology, management process, the location of personnel, the agility of information delivery, facilities and interrelationship among teachers as the dimensions for learner satisfaction. Learner satisfaction is also regarded as learning environment, while evaluation of learning outcome and achievement after learning. Teacher/learner selfassessment of performance has to do with learners having confidence and ability to acquire knowledge to demonstrate explicit behaviours. Yen and He (2001) confirmed that the use of technology in teaching can enhance effective learning; Information technology is the only supporting tool. According to the above reasoning,

\section{Teachers Capacity Development}

According to Young and king (2002) and Egbo, (2011) the issue of teacher capacity development is a global phenomenon that is not taken seriously both in the developed and underdeveloped world. In other words, for positive result in education system at any level, the government and school authorities should take teacher capacity development very serious. Therefore, what is capacity development? According to Panigrahi (2012) developing teachers' capacity is the act of attending training, workshop, and conference by teacher for development academically and professionally in order to enhance teaching instruction and activities for promoting learning. Stocklin (2011) also sees it as a program designed to ensure that teachers participate in activities that will upgrade and develop knowledge and skills that are effective for classroom activities. In other words, it is teachers intensive activities carried out outside the classroom to enhance skills, knowledge of subject area and activities for motivating learners to achieve academic success and educational goals.

\section{The Need for Teachers' Development}

For better result and efficient teaching, there is need for teachers to undergo training to develop and enhance their capacity as classroom teachers. In view of the need for teachers' capacity development, Tam (2014) is of the opinion that the efficiency and effectiveness of teachers depend on their ability to disseminate the course contents in the curriculum. It should be noted that pre-training of a teacher is not enough guarantee to say that the teacher is qualified but needs additional training to meet the trend of changes in curriculum. Asare (2011) supported the view that for quality education and students' output is as a result of teachers' competence which has to be from regular training. Therefore, the teacher capacity development training should focus on classroom activities to meet the needs of the students. According to Egbo 2011 and O'Brien et al., (2013) countries where teachers receive regular capacity development training will be of advantage to the teachers themselves, the schools that provide opportunities for teachers' capacity development, and the students who receive the outcome of the knowledge gained by the teachers. They also add that, teacher capacity development is to enhance professional competence and excellent education system. In other words, the following can be considered as the needs for teachers' capacity development:

1. To be able to assist students to think critically and be creative

2. To help students solve their academically, socially, and emotionally short comings.

3. To develop students' participation and collaborative learning activities.

4. Ability to inculcate the acquired knowledge to students in the classroom. 
5. To promote extra-curricular activities within and outside the school environment.

\section{The Effects of Teacher Capacity Development on Academic Achievement}

Employee empowerment as teacher development moderating for total quality management has received recognition by researchers who studied its role in academic achievement. Pelton (2013) carried out research on role of teacher training on academic achievement and highlights that teacher capacity development enhances their performance in the classroom. The findings of his research show that there is significant relationship between teacher development and academic achievements of students. He also encouraged that workshop, seminar, conferences and in service training be organized and sponsored for teachers.

Furthermore, Koellner and Jacobs (2014) did their research on mathematics workshop for teachers and academic achievement using adaptive model. They found that students in the class of teachers who went for teacher capacity development did better and had positive and significant relationship on their academic performance. Therefore, they concluded that organizing workshop for teachers will have beneficial impact on students' academic achievement and should be a continuous program for teachers.

Fresko and Alhija (2014) also researched on using seminar as forum for teachers' capacity development training and academic achievement. The forum was used to develop confidence in teachers and concluded that is the right forum for enhancing confidence in teachers to improve learners' performance. They add that it should be a continuous program organized for teachers to discuss a topic in their field of specialization to boost confident in them and advised that stakeholders in education should take it very serious.

In addition, investigation was carried out by Collins (2014) on, the effects of teacher training on students' academic performance in English language. The experimental design study was carried out on students English language course and found that teacher training had impact on students' academic achievement. He also found that few teachers were given opportunity to go for capacity training while the result of his study was not encouraging, he therefore, advice that further study been carried out by future researchers across the globe.

Jeffery and Sorto (2012), Dash (2012), and Smith and Philips (2013) did research on the effect of teacher capacity training on education achievement in schools. The first finds that performance of students in his study was low, meaning that method of training teachers should be improved upon. Dash on his part, carried out research on online teacher development on students' academic achievement in mathematics and found that the result was not encouraging and there was low relationship between the teachers training and students' academic performance. He concluded that better ways of developing the teachers' capacity should be created in order to improve students' performance. While last in their research findings had poor significant relationship with teachers training and students' performance in mathematics, they advised that prompt regular training of teachers is necessary for the benefits of the students and man power development.

\section{Teachers' Competence and Performance}

Competence on the part of the teacher is according to American Heritage Dictionary (2006) teacher being adequately qualified with ability to impact knowledge and skills. It is the ability to achieve positive difference in learners after taught. Jose (2009), and Adeyemi (2013) Competence refers to a behaviour, skills, and knowledge that is displayed with less problem by teacher in order to achieve the set goals and intended academic outcome. Therefore, the academic performance of students is used to measure the achievement of the school (Booth \& Saunders, 2014; \& Fox, 2014).

The term competence has been used by different researchers in different ways leading to it having many definitions in teacher education and job performance. It is described by jose (2007) to explain competency 
based teacher education that indicates values, skills, and knowledge that teachers need to complete teacher education and perform effectively. However, professional competence has to do with the knowledge needed for understanding learners and their learning ability, knowing the curriculum and how to implement it, and the knowledge of subject matters, as well as classroom management, assessment and recording.

Academic performance is a term used to describe or measure effectiveness of teachers and the school at all levels. According to Adeyemi (2011) the academic performance of learners can also be used to judge performance of the teacher to either be good or bad too. Teachers' academic performance can also be referred to the status of the students at a particular point in time after series of examinations and this depicts teachers' performance outcome. To support the above views, Fose (2014) described teachers' academic performance as the ability to demonstrate capability to impact knowledge effectively on students to bring about positive changes in the students both academically or socially. It is also helps to show whether the aims and objectives of the school is achieved.

\section{JOB SATISFACTION}

By definition, job satisfaction is the reaction of individuals towards their jobs and the source of satisfaction that comes from the intrinsic and extrinsic factors pertaining to the job contents. In the academic setting, academic researchers would prefer to define job satisfaction based on the dual theory of Herzberg, the hygiene and motivator factors (Lacy \& Sheehan, 1997; Rad \& Yarmohammadin, 2006; Ssesanga \& Garret, 2005). The study carried out by Malik, Nawab, Naeem \& Danish (2010) on 331 teachers in two public universities in Pakistan revealed that job satisfaction is paramount to the organization commitment to achieve the organization set target. Job satisfaction is linked with many organizational contextual factors like salary and incentive, working condition, security, team work, promotion, advancement, reward and recognition. The dimension explains has follows:

(1) Salary and Incentives: Salaries is one of the effective motivator. Personnel managers must consider four major components of a salary structures. These are the job rate, which relates to the importance the organization attaches to each job; payment, which encourages workers or groups by rewarding them according to their performance; personal or special allowances, associated with factors such as scarcity of particular skills or certain categories of information professionals or librarians, or with long service; and fringe benefits such as holidays with pay, pensions, and so on. It is also important to ensure that the prevailing pay in other library or information establishments is taken into consideration in determining the pay structure of their organization.

(2) Working condition refers to the availability of the basic infrastructure like the school buildings, enough space, proper ventilation, furniture, teaching learning material, safe environment which is free from the health hazards and proper place for the teacher to plan and work.

(3) Intrinsic Reward refers to the achievement, recognition, responsibility, advancement, the work itself and the possibility of growth.

\section{Conclusion}

The above discussions on the effects of TQM on students and school achievements in Pakistan suggested the following:

1. Intensified efforts should be made by school authorities on effective supervision of teachers and students' behaviour to improve quality education.

2. Efforts should be made to maintain efficient performance of schools and students in Pakistan. 
3. Schools' management committees and PTA of schools should come together to intensify efforts to strengthened the schools' performance in the country.

4. Also, these bodies should be part of the governing boards that will ensure grassroots' participation in school processes in the nation.

5. The principals and heads of schools in the country should undergo leadership trainings to enhance leadership skills which can help them display TQM skills for leadership enhance harmonious relationship among stakeholders of schools to provide the appropriate learning environments.

6. The school authority should work hand in hand with the community heads to adequately financial schools and give opportunities for teachers training, adequate classroom infrastructure, and teaching and learning materials to promote adequate and convulsive learning environment in the nation.

\section{References}

Adeyemi, T.O. (2013). Entry qualifications as predictors of performance in Final year bachelor of education degrees in universities in Ondo and Ekiti State, American Journal of Economics 3(1) 43-51

Adeyemi, T.O. (2011). A comparative study of students' academic performance in public examinations in secondary schools in Ondo and Ekiti State: Current Research Journal of Economics. 3(2) 36-42.

Alabere, R.A., Hassan, A., \& Suleiman, Y. (2015). Examining the use of proverbs in teaching English as a second language: an implication for secondary school principal, International E-Journal for Research in ELT. 1(3), 14-28

Alabere, R.A, Shapii, B.S., \& Hassan A. (2015). Co-curricular activities and achievement in language learning of secondary school students, Journal of Business, Education, and Social Sciences. 35(2) 18-31

Allen, M. J. (2007) Assessing Academic Programs in Higher Education. Bolton, Massachusetts: Anker Publishing Company.

Asare, K.B. \& Nti, S.K. (2014). Teacher education in Ghana. SAGE Open, 4(2) 43-52

Biner, P.(1997), Relative academic performance and its relation to facet and overall satisfaction with interactive tele-courses. Distance Educ., 18, 2, 318.

Booth, S. \& Saunders, C. (20144). Operationalizing academic performance: implementing teaching performance expectations, association for tertiary education management and tertiary education facilities management' association 7.

Caprara, G.V., Barbaranelli, C., Steca, P., \& Malone, P. S. (2006). eachers' self-efficacy beliefs as determinants of job satisfaction and students' academic achievement: A study at the school level. Journal of School Psychology, 44, 473-490.

Collins, J.C. (2014). Evaluation of teacher training and student achievement in the reading first program: Dissertation Abstract International Section A, 74

Dash, S. (2012). Impact of online professional development on teacher quality and student achievement in fifth grade mathematics: Journal of Research on Technology in $\quad$ Education 45(1) 1-26

Egbo, B. (2011). Teacher capacity building and effective teaching and learning a seamless connection: Mediterranean Journal of Social Sciences, 2(5), 1-7

Fox, C. L. \& Buther, I. (2014). Evaluating the effectiveness of a school-based counselling service in the UK British Journal of Guidance and Counselling, 37(2), 95-106

Hoffman, R.P.(1996), Levels of Technology Use and Instructional Innovation: PhD Thesis, San Diego State University.

Jones, B. L.(1996), Self-efficacy and personal goals in classroom performance: The effect of task experience, PhD Dissertation, Graduate School of Management, Kent State University

Jose, P. A. F (2009). A comparative analysis of teacher competence and its effect on pupil performance in upper primary schools in mozambique and other sacmeq countries. PhD thesis, University of Pretoria Pretoria

Koellner, K. \& Jacobs, J. (2014).distinguishing models of professional development: the case of an adaptive models impact on teachers' knowledge, Journal of Teacher Education,

1(1) $98-109$ 
Lee, Y. (2011). A study on the effect of teaching innovation on learning effectiveness with learning satisfaction as a mediator, World Transactions on Engineering and WIETE 9(2),93-101

Lin, I.M. (2002), Innovative teaching - starting from the professional ethics of teachers. Secondary Educ., 4, 36-49

Malik, M. E., Nawab, S., Naeem, B., \& Danish, R. Q. (2010). Job satisfaction and organizational commitment of university teachers inpublic sector of Pakistan. International Journal of Business and Management, 5(4), 17-26.

Murad, A. and Rajesh, K. S.(2010). Implementation of total quality management in higher education: Asian Journal of Business Management, 2(1), 9-16.

Mark, R. L. (2016). The Effect of the Adequacy of School Facilities on Students' Performance and Achievement in Technology and Livelihood Education, International Journal of Academic Research in Progressive Education and Development,5(1)45-58

Parigrahi, M. R. (2012). Capacity building of teachers through distance mode using teleconferencing as an innovative tool, Journal of Technology, 83(11)1-7

Pelton, J. A. (2013). Assessing graduate teacher training programs: can a teaching seminar reduce anxiety and increase confidence? Journal of Teaching Sociology, 9 (2) 5-16

Popham, W. J. (2010a).Educational assessment: What school leaders need to understand Thousand Oaks, CA: Corwin Press

Popham, W. J. (2010b). Classroom assessment: What teachers need to know Upper Saddle River, NJ : Prentice Hall.

Rad, A. M. M., \& Yarmohammadian, M. H. (2006). A study of relationship between managers' leadership style and employees' job satisfaction. Leadership in Health Service, 19(2), 11-28.

Ssesanga, K., \& Garrett, R. M. (2005). Job satisfaction of university academics: Perspectives from Uganda. Higher Education Journal, 50(1), 33-56.

Tahidu, A., Bawa, Mohammed W., and Abubakari A. (2014). Assessment of the effects of total quality management on school performance in the education directorate, International Journal of Interdisciplinary and Multidisciplinary Studies (IJIMS), 1,(5),294-308

Tschannen-Moran, M., \& Woolfolk Hoy, A. (2007). The differential antecedents of self-efficacy beliefs of novice and experienced teachers: Teaching and Teacher Education, 23(1), 944-956.

Wang, C.S. (2000), The evaluation criteria of information situation when integrating information technology into various teaching subjects. J. of Information and Educ., 77, 36-46.

Wang, H.H. (2002), Website design and exploration of schools dynamic database. J. of Secondary Educ., 9, 467-508

Wu, C.S.(2002), Important concept and implementation strategy of creative teaching. Taiwan Education, $614,2-8$.

Yen, Y.C. and He, J.K.(2001), Integrating information into the field of teaching in health and physical education. Teachers' World, 112, 71-75 